\title{
Selective Inhibition on Growth and Photosynthesis of Harmful Cyanobacteria (Microcystis aeruginosa) by Water Soluble Substances of Dendranthema indicum Flowers
}

\author{
Yunni Gao*@ , Fang Zhang, Jing Wu, Hui Yang, Jing Dong, Man Zhang and Xuejun Li \\ Engineering Lab of Henan Province for Aquatic Animal Disease Control, Engineering Technology Research \\ Center of Henan Province for Aquatic Animal Cultivation, College of Fisheries, Henan Normal University, \\ Xinxiang 453007, China; zhangfang_f@163.com (F.Z.); WJ15736970758@163.com (J.W.); \\ hui316asd@163.com (H.Y.); happydj111@163.com (J.D.); mandy@htu.edu.cn (M.Z.); xjli@htu.cn (X.L.) \\ * Correspondence: gaoyn@htu.cn; Tel.: +86-373-3326-556
}

Received: 19 May 2020; Accepted: 13 July 2020; Published: 15 July 2020

\begin{abstract}
Harmful cyanobacterial blooms become serious environmental issues in various waterbodies, including aquaculture ponds, which inherently need a high biomass and healthy composition of phytoplankton to sustain their high productivity. Indoor bioassays were conducted to investigate the effects of an aqueous extract of Dendranthema indicum flowers on cyanobacteria and green algae species. The thermal stability and polarity of the water-soluble active substances of $D$. indicum flowers were also assessed based on the growth and photosynthesis responses of Microcystis aeruginosa. There was obvious growth promotion of green algae, including Chlorella vulgaris, Kirchneriella sp. and Haematococcus pluvialis and strong growth inhibition of toxigenic and non-toxigenic M. aeruginosa by aqueous extracts of $D$. indicum flowers at concentrations ranging from 0.5 to $2.0 \mathrm{~g} \cdot \mathrm{DW} \cdot \mathrm{L}^{-1}$. The cell concentrations of $M$. aeruginosa and C. vulgaris were $46.5 \%$ and $242.2 \%$ of those in the corresponding controls after a 10-day exposure to aqueous extracts of $D$. indicum flowers at $1.0 \mathrm{~g} \cdot \mathrm{DW} \cdot \mathrm{L}^{-1}$. There must be some water-soluble active allelochemicals released from $D$. indicum flowers that are responsible for the selective inhibition of $M$. aeruginosa rather than green algae. The inhibition ratio of the growth and photosynthesis of $M$. aeruginosa by aqueous extracts of D. indicum flowers at $2.0 \mathrm{~g} \cdot \mathrm{DW} \cdot \mathrm{L}^{-1}$ prepared with water at $25^{\circ} \mathrm{C}$ and $100{ }^{\circ} \mathrm{C}$ were above $90 \%$ and $80 \%$ compared to the cell density and performance index on absorption basis (PIABS) value of $M$. aeruginosa in the control on day 6, without significant differences. It indicates that the active substances of $D$. indicum flowers were thermally stable. The methanol fraction eluted from solid phase extraction (SPE)-enriched aqueous extracts of $D$. indicum flowers showed the strongest inhibition of the growth and photosynthesis of $M$. aeruginosa compared to the other four fractions. It indicates that the most polar substances of $D$. indicum flowers were responsible for the selective inhibition of $M$. aeruginosa. More experiments are required to identify the responsible active substances and reveal the underlying mechanisms of aqueous extracts of $D$. indicum flowers that selectively inhibit cyanobacteria and regulate the phytoplankton community structure.
\end{abstract}

Keywords: Dendranthema indicum flowers; green algae; cyanobacteria; chemical characteristics; photosynthetic activity

\section{Introduction}

Harmful cyanobacterial blooms have increasingly become a global environmental and public issue due to their damage to water ecosystems and threat to human health [1]. The frequency, 
magnitude, and duration of harmful cyanobacterial blooms have been found to have increased globally [2]. Microcystis aeruginosa is the most widely distributed species causing harmful cyanobacterial blooms in freshwater worldwide [3]. It is also the most frequently found cyanobacterial taxon in aquaculture water [4]. Some M. aeruginosa strains naturally produce microcystins, e.g., microcystin-YR, microcystin-LR, and microcystin-RR, or off-flavor compounds, e.g., geosmin and 2-methylisoborneol [5], which have substantial adverse impacts on drinking water and aquatic food security and consequently present health risks to humans [6].

Multiple countermeasures, including nutrient management $[7,8]$, hydrodynamic regulation $[9,10]$, chemical treatments [11,12], and biological control [13,14], have been developed and used to control cyanobacterial blooms. However, it is still a challenge to control harmful cyanobacterial blooms effectively and protect harmless aquatic organisms, especially for aquaculture ponds. There are $2.53 \times 10^{6}$ ha of pond-based freshwater aquaculture in China [15], which accounts for more than half of the total aquaculture area in China and contributes to the global aquatic food supply [16]. The most urgent need is for green technology to selectively inhibit cyanobacteria but promote the growth of beneficial algae to ensure pond fishery productivity.

It has been reported that some cyanobacteria species are more susceptible than green algae to active substances derived from aquatic plants, such as Myriophyllum spicatum [17,18], and terrestrial plants, such as Salix atrocinerea [19]. This provides a possibility to explore plant-derived chemical resources to regulate and improve phytoplankton community structure in aquaculture ponds. Compared to aquatic plants, terrestrial plants contain more abundant active compounds, which have been widely used in the fields of traditional Chinese medicine and biopesticides [20,21]. They have been also used as feed additives and immunostimulants to improve aquaculture environments and aquatic product quality [22]. Compositae is the largest family of angiosperms, it is widely distributed throughout the world and is famous for its bioactivity and various active secondary metabolites, including terpenoids, polyacetylenes, phenolics, and organic acids [23]. Some of these compounds have been isolated and identified to be antimicrobial agents [24], anti-inflammatory agents [25], and antimalarial drugs [26]. The inhibition effects of Compositae plants on $M$. aeruginosa were found for a few species, such as Artemisia lavandulifolia [27], however, whether they can selectively control harmful cyanobacteria rather than beneficial algae, so as to regulate freshwater phytoplankton composition, is not clear.

Dendranthema indicum is one available Compositae species that is widely distributed in most areas of China. Its dried buds and flowers have been used as a popular tea, as an antipyretic to clear the eye and the mind, and as a remedy for common symptoms including headache, dizziness, and red eye [28]. It has been suggested to be a valuable source of antimicrobial ingredients in the food industry [29]. To assess its potential to control harmful cyanobacteria, our preliminary experiments indicated that $D$. indicum flowers could effectively inhibit the growth of one M. aeruginosa strain. As for its selectivity, we proposed a hypothesis that $D$. indicum flowers may selectively inhibit $M$. aeruginosa rather than green algae. To test this hypothesis, the concentration-dependent effects of water extracts of $D$. indicum flowers were investigated using the green algae Chlorella vulgaris and the cyanobacteria M. aeruginosa. Its species-specific inhibition effects were further tested using two other green algae species and two M. aeruginosa strains. To explore the responsible substances, the basic chemical properties, including the thermal stability and polarity of the selective inhibition substances from $D$. indicum flowers, were also investigated in two separate experiments, where chlorophyll fluorescence rise kinetics were observed to reveal their effects on the status and performance of photosynthetic system II (PSII) in M. aeruginosa cells.

\section{Materials and Methods}

\subsection{Culture Condition}

Two harmful cyanobacterial strains, i.e., one toxigenic (FACHB 905) and one non-toxigenic M. aeruginosa (FACHB 526), and three beneficial green alga strains, i.e., C. vulgaris (FACHB 8), 
Kirchneriella sp. (FACHB 1433) and Haematococcus pluvialis (FACHB 1164), were purchased from the Freshwater Algae Culture Collection at the Institute of Hydrobiology. All the cultures were grown in $250 \mathrm{~mL}$ conical flasks containing $100 \mathrm{~mL}$ of autoclaved BG 11 medium under $25 \mu \mathrm{mol} \cdot \mathrm{m}^{-2} \cdot \mathrm{s}^{-1}$ of light intensity with a $12: 12 \mathrm{~h}$ light: dark cycle at $25^{\circ} \mathrm{C}$. The cultures were manually shaken twice each day and cells in exponential growth phase were prepared for the experiments.

\subsection{Experimental Design for Selective Effects of Aqueous Extract from D. indicum Flowers}

The dry flowers of D. indicum used in the study were collected from Dabie Mountain, Anhui Province, China. They were added into glass beakers, immersed in distilled water, and then they stood at room temperature for $8 \mathrm{~h}$ to prepare the aqueous extracts of $D$. indicum flowers. The aqueous extracts were filtered by sterile gauze and a $0.22 \mu \mathrm{m}$ filter membrane in turn, and then they were ready for the experiments.

To analyze the concentration-dependent effects of aqueous extracts of $D$. indicum flowers on phytoplankton species, the cells of $C$. vulgaris and toxigenic $M$. aeruginosa were used for bioassays. The final concentration of the aqueous extracts of $D$. indicum flowers in the bioassays were equivalent to adding $0.5,1.0,2.0,4.0$ and $8.0 \mathrm{~g}$.DW D. indicum flowers per liter, respectively. The initial cell density for both strains was between $5.0-5.5 \times 10^{5}$ cells $\cdot \mathrm{mL}^{-1}$. The control for each strain without the addition of plant aqueous extracts was set simultaneously. Three replicates were prepared for both the treatments and controls. The bioassays lasted 10 days. Sub-samples were collected at 9 a.m. on days 0 , $2,4,6,8$, and 10 for cell counts.

To further testify the species-specific inhibition by aqueous extracts of $D$. indicum flowers, the responses of Kirchneriella sp. and H. pluvialis, toxigenic and non-toxigenic M. aeruginosa, to aqueous extracts of $1.0 \mathrm{~g} \cdot \mathrm{DW} \cdot \mathrm{L}^{-1} \mathrm{D}$. indicum flowers, were compared. The initial $\mathrm{OD}_{680}$ for each strain was 0.03 , and the corresponding cell density was $6.7 \times 10^{4}$ cells $\cdot \mathrm{mL}^{-1}$ for Kirchneriella sp., $9.8 \times 10^{3}$ cells $\cdot \mathrm{mL}^{-1}$ for H. pluvialis, $5.3 \times 10^{5}$ cells $\cdot \mathrm{mL}^{-1}$, and $5.2 \times 10^{5}$ cells $\mathrm{mL}^{-1}$ for non-toxigenic and toxigenic M. aeruginosa. The control for each strain without the addition of plant aqueous extracts was set simultaneously. Three replicates were prepared for both the treatments and controls. The bioassays lasted 3 days. Sub-samples were collected at the beginning and the end for cell counts and photosynthesis pigments analysis.

\subsection{Characterization of Its Selective Inhibition Substances}

To test the thermal stability of selective inhibition substances from $D$. indicum flowers, pure water at $25^{\circ} \mathrm{C}$ and $100^{\circ} \mathrm{C}$ was used to prepare aqueous extracts of $D$. indicum flowers. Pure water in conical flasks was placed in an incubator at $25^{\circ} \mathrm{C}$ for $12 \mathrm{~h}$ to obtain the extraction water at $25^{\circ} \mathrm{C}$. Pure water in conical flasks was boiled at $100^{\circ} \mathrm{C}$ to obtain the extraction water at $100^{\circ} \mathrm{C}$. Two kinds of aqueous extracts from $D$. indicum flowers were prepared as per the protocols mentioned in Section 2.2, and cooled to room temperature. The toxigenic $M$. aeruginosa cells were used to compare the inhibition effects of the two kinds of aqueous extracts of $2.0 \mathrm{~g} \cdot \mathrm{DW} \cdot \mathrm{L}^{-1} \mathrm{D}$. indicum flowers in a 9-day bioassay. The control without plant aqueous extracts was set simultaneously. Three replicates were prepared for both the treatments and controls. The initial cell density of $M$. aeruginosa was $4.6 \times 10^{5}$ cells. $\mathrm{mL}^{-1}$. Sub-samples were collected on day 0 , day 3 , day 6 , and day 9 to measure the cell density, chl $a$ concentration, and chlorophyll fluorescence parameters of M. aeruginosa.

To test the polarity of selective inhibition substances from $D$. indicum flowers, the aqueous extracts from $D$. indicum flowers were prepared as per the protocols mentioned in Section 2.2. The prepared aqueous extracts were enriched using solid phase extraction (SPE) with activated Oasis HLB cartridges (500 mg, 6cc. Waters, Milford, MA, USA). The five enriched cartridges were eluted with hexane, dichloromethane, ethyl acetate, acetone, and methanol, respectively. The eluted solvents were dried with nitrogen, and the eluted fractions were re-dissolved in DMSO for bioassays with toxigenic M. aeruginosa in a 9-day bioassay. The initial cell density of M. aeruginosa was $4.5 \times 10^{5}$ cells $\cdot \mathrm{mL}^{-1}$, and the final concentration of each eluting fraction in the bioassay was equivalent to $2.0 \mathrm{~g} \cdot \mathrm{DW} \cdot \mathrm{L}^{-1}$ 
D. indicum flowers. The control without eluting fractions was set simultaneously. Three replicates were prepared for both the treatments and controls. The final volume of the cosolvent DMSO in the control and the treatments accounted for $0.1 \%$, which showed no significant inhibition of M. aeruginosa in our preliminary experiment. Sub-samples were collected on day 0, day 3, day 6, and day 9 to measure the cell density, chl a concentration, and chlorophyll fluorescence parameters of M. aeruginosa.

\subsection{Determination of Growth Parameters}

Five-milliliter sub-samples were collected every time and fixed with Lugol's solution. A cell count was conducted for each sample with a Sedgewick Rafter counter under light microscopy (BA210, MOTIC, Xiamen, China) at $\times 400$ magnification. The daily growth rate of each strain was calculated according to the following equation

$$
\text { Daily growth rate }\left(\text { day }^{-1}\right)=\ln \left(\mathrm{N}_{\mathrm{t} 2} / \mathrm{N}_{\mathrm{t} 1}\right) /\left(\mathrm{t}_{2}-\mathrm{t}_{1}\right)
$$

where $\mathrm{N}_{\mathrm{t} 2}$ and $\mathrm{N}_{\mathrm{t} 1}$ are the counted cell density of one strain in the control or treatments on the days of $t_{2}$ and $t_{1}$, respectively.

\subsection{Measurement of Photosynthesis Pigments}

A 5-mL subsample of each culture was centrifuged at $7100 \times g$ for $10 \mathrm{~min}$ and the pellets were harvested and extracted with 95\% ethanol for $24 \mathrm{~h}$ in the dark. The extracts were centrifuged again at $7100 \times g$ for a further $10 \mathrm{~min}$. The absorbance of the supernatant was measured at 665, 649, and $470 \mathrm{~nm}$. The concentrations of $\operatorname{chl} a$ and carotenoids in the extracts were calculated as described previously [30].

\subsection{Measurement of Chlorophyll Fluorescence Parameters}

Chlorophyll fluorescence transient O-J-I-P and JIP tests were used to assess the effects of aqueous extracts of $D$. indicum flowers on the photosynthetic activity of $M$. aeruginosa. A 5-mL subsample of $M$. aeruginosa was collected in a tube, dark-adapted for $20 \mathrm{~min}$, and the chlorophyll fluorescence rise kinetics (OJIP curves) were measured with an AquaPen-C AP-C 100 fluorometer (Photon Systems Instruments, Drasov, Czech Republic) according to the manufacturer's instructions. The fluorescence intensity at $2 \mathrm{~ms}$ (J-step), $30 \mathrm{~ms}$ (I-step), and the maximum fluorescence (P-step) were denoted as $\mathrm{Fj}$, Fi, and Fp, respectively. Selected JIP test parameters quantifying PSII behavior were automatically calculated from the above time-resolved fluorescence and the formulae listed in Table 1 [31].

Table 1. The formulae and illustrations of the selected JIP test parameters in the study.

\begin{tabular}{|c|c|c|}
\hline Parameters & Formulae and Terms & Illustrations \\
\hline $\mathrm{Vj}$ & $\mathrm{Vj}=(\mathrm{Fj}-\mathrm{Fo}) /(\mathrm{Fm}-\mathrm{Fo})$ & Relative variable fluorescence intensity at the J-step \\
\hline Mo & $\mathrm{Mo}=4\left(\mathrm{~F}_{300 \mu \mathrm{s}}-\mathrm{Fo}\right) /(\mathrm{Fm}-\mathrm{Fo})$ & Approximated initial slope of the fluorescence transient \\
\hline \multicolumn{3}{|c|}{ Quantum efficiencies or flux ratios } \\
\hline $\mathrm{Fv} / \mathrm{Fm}$ & $\mathrm{Fv} / \mathrm{Fm}=\mathrm{TRo} / \mathrm{ABS}=1-\mathrm{Fo} / \mathrm{Fm}=\varphi \mathrm{Po}$ & Maximum quantum yield for primary photochemistry \\
\hline$\Psi$ Ч & $\Psi o=\mathrm{ETo} / \mathrm{TRo}=(\mathrm{Fm}-\mathrm{Fj}) /(\mathrm{Fm}-\mathrm{Fo})$ & Probability that a trapped exciton moves an electron \\
\hline$\varphi \mathrm{Eo}$ & $\varphi \mathrm{Eo}=\mathrm{ETo} / \mathrm{ABS}=(\mathrm{Fm}-\mathrm{Fj}) / \mathrm{Fm}$ & Quantum yield for electron transport $($ at $t=0)$ \\
\hline \multicolumn{3}{|c|}{ Specific activities or specific fluxes } \\
\hline $\mathrm{ABS} / \mathrm{RC}$ & $\mathrm{ABS} / \mathrm{RC}=\mathrm{Mo} \cdot(1 / \mathrm{Vj}) \cdot(1 / \varphi \mathrm{Po})$ & Absorption flux per reaction center \\
\hline TRo/RC & $\mathrm{TRo} / \mathrm{RC}=\mathrm{Mo} \cdot(1 / \mathrm{Vj})$ & Trapped energy flux per reaction center $($ at $t=0)$ \\
\hline $\mathrm{ETo} / \mathrm{RC}$ & $\mathrm{ETo} / \mathrm{RC}=\mathrm{Mo} \cdot(1 / \mathrm{Vj}) \cdot \Psi_{\mathrm{o}}$ & Electron transport flux per reaction center $($ at $t=0)$ \\
\hline $\mathrm{DIo} / \mathrm{RC}$ & $\mathrm{DIo} / \mathrm{RC}=(\mathrm{ABS} / \mathrm{RC})-(\mathrm{TRo} / \mathrm{RC})$ & Dissipated energy flux per reaction center $($ at $t=0)$ \\
\hline \multicolumn{3}{|c|}{ Performance indexes } \\
\hline PIABS & $\begin{array}{c}\mathrm{PIABS}=(\mathrm{RC} / \mathrm{ABS}) \cdot[\varphi \mathrm{Po} /(1- \\
\varphi \mathrm{Po})] \cdot[\Psi \mathrm{O} /(1-\Psi \mathrm{o})]\end{array}$ & Performance index on absorption basis \\
\hline
\end{tabular}




\subsection{Data Analysis}

Data were analyzed with Microsoft Excel 2010 and SPSS 23 (IBM, Armonk, NY, USA). The inhibition ratio of plant aqueous extracts or the eluting fractions on the targeted organisms was calculated according to the following equation:

$$
\text { Inhibition ratio }(\%)=100 \times\left(\mathrm{P}_{\mathrm{c}}-\mathrm{P}_{\mathrm{t}}\right) / \mathrm{P}_{\mathrm{c}}
$$

where $P_{t}$ is the value of each parameter for the specific tested strains in the treatments and $P_{c}$ is that in the control. ANOVA and a subsequent Tukey's test were used to analyze the differences between treatments. Statements of significance refer to a less than $5 \%$ level of statistical confidence.

\section{Results}

\subsection{Concentration-Dependent Effects of Aqueous Extracts from D. indicum Flowers}

The cell concentrations of $C$. vulgaris increased from $5.5 \times 10^{5}$ cells $\cdot \mathrm{mL}^{-1}$ to $7.9 \times 10^{6}$ cells $\mathrm{mL}^{-1}$ in the control over 10 days. Aqueous extracts of $D$. indicum flowers at $0.5-2.0 \mathrm{~g} \cdot \mathrm{DW} \cdot \mathrm{L}^{-1}$ significantly promoted the growth of $C$. vulgaris $(p<0.05)$. When the concentrations of $D$. indicum flowers in the treatments were $0.5 \mathrm{~g} \cdot \mathrm{DW} \cdot \mathrm{L}^{-1}, 1.0 \mathrm{~g} \cdot \mathrm{DW} \cdot \mathrm{L}^{-1}$, and $2.0 \mathrm{~g} \cdot \mathrm{DW} \cdot \mathrm{L}^{-1}$, the growth of $C$. vulgaris was $235.5 \%$, $384.2 \%$, and $303.4 \%$ of that in the control on day 4 , respectively, and $184.5 \%, 242.2 \%$, and $262.7 \%$ on day 10 , respectively. When the concentrations of $D$. indicum flowers were $4.0 \mathrm{~g} \cdot \mathrm{DW} \cdot \mathrm{L}^{-1}$ and $8.0 \mathrm{~g} \cdot \mathrm{DW} \cdot \mathrm{L}^{-1}$, the growth of $\mathrm{C}$. vulgaris was $17.0 \%$ and $12.9 \%$ relative to the control on day 4 , and $29.3 \%$ and $2.0 \%$ on day 10 (Figure $1 \mathrm{~A}$ ). The growth of $C$. vulgaris was significantly inhibited by aqueous extracts of $D$. indicum flowers at a concentration higher than $4.0 \mathrm{~g} \cdot \mathrm{DW} \cdot \mathrm{L}^{-1}(p<0.05)$.

The cell concentrations of $M$. aeruginosa increased from $5.0 \times 10^{5}$ cells $\cdot \mathrm{mL}^{-1}$ to $2.1 \times 10^{7}$ cells $\cdot \mathrm{mL}^{-1}$ in the control over 10 days. A concentration-dependent inhibition of aqueous extracts of $D$. indicum flowers at $0.5-8.0 \mathrm{~g} \cdot \mathrm{DW} \cdot \mathrm{L}^{-1}$ on the growth of M. aeruginosa was recorded (Figure 1B). In the treatments with aqueous extracts of $D$. indicum flowers at $0.5 \mathrm{~g} \cdot \mathrm{DW} \cdot \mathrm{L}^{-1}$, the growth of $M$. aeruginosa from day 4 to day 10 ranged from $89.0 \%$ to $57.2 \%$ of that in the control. When the concentration of $D$. indicum flowers was $1.0 \mathrm{~g} \cdot \mathrm{DW} \cdot \mathrm{L}^{-1}$, the growth of $M$. aeruginosa from day 4 to day 10 ranged from $49.0 \%$ to $46.5 \%$ of that in the control. When the concentration of $D$. indicum flowers was $2.0 \mathrm{~g} \cdot \mathrm{DW} \cdot \mathrm{L}^{-1}$ or higher, cell concentrations of $M$. aeruginosa were even lower than those on day 0 , and lower than $10 \%$ of those in the control on each sampling day, indicating thorough inhibition by aqueous extracts of D. indicum flowers.
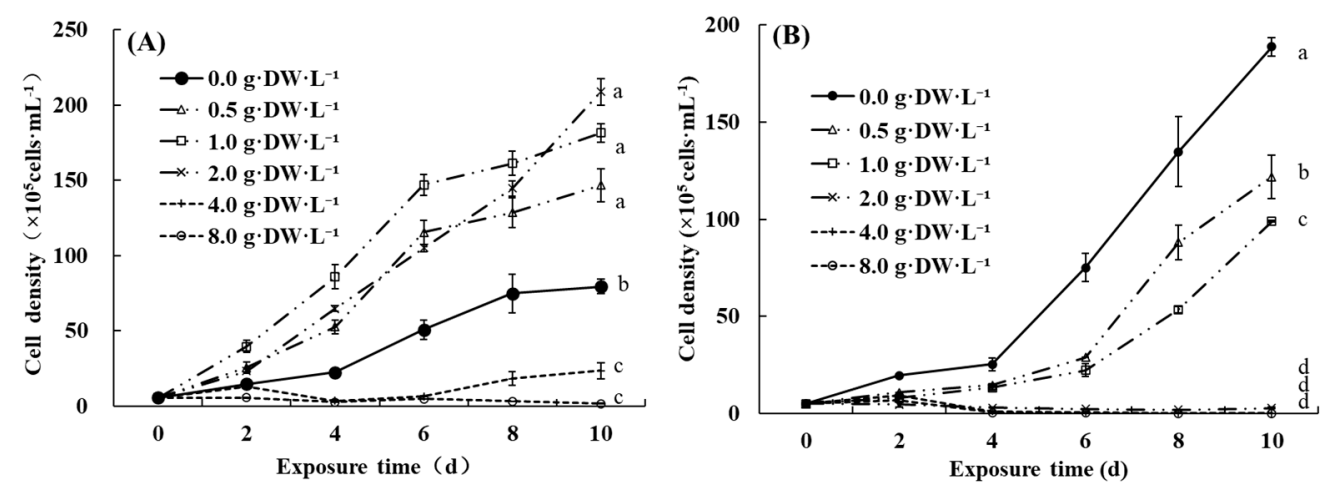

Figure 1. The cell density changes of C. vulgaris (A) and M. aeruginosa (B) exposed to varying concentrations of aqueous extracts of $D$. indicum flowers $\left(\mathrm{g} \cdot \mathrm{DW} \cdot \mathrm{L}^{-1}\right)$ in mono-culture bioassays. Different letters indicate significant differences among varying groups at $p<0.05$ level. 


\subsection{Species-Specific Effects of Aqueous Extracts from D. indicum Flowers}

During the 3-day bioassays, the responses of two green algae strains and two cyanobacterial strains to aqueous extracts from $D$. indicum flowers differed significantly $(p<0.05)$. The daily growth rate, $\operatorname{chl} a$, and carotenoid contents of Kirchneriella sp. and H. pluvialis were promoted significantly compared to the control, whereas those of toxigenic and non-toxigenic M. aeruginosa were inhibited significantly by the aqueous extracts from $D$. indicum flowers (Figure $2 \mathrm{~A}-\mathrm{C}$ ). The promotion ratio of Kirchneriella sp. and H. pluvialis by the plant extracts was $126.4 \%$ and $58.6 \%$ based on the daily growth rate, $40.4 \%$ and $72.9 \%$ based on chl $a$ content, and $35.5 \%$ and $84.5 \%$ based on carotenoid contents. The inhibition ratio of toxigenic and non-toxigenic M. aeruginosa by the plant extracts was $33.3 \%$ and $31.6 \%$ based on daily growth rate, $20.7 \%$ and $13.8 \%$ based on chl $a$ content, and $23.5 \%$ and $16.7 \%$ based on carotenoid contents (Figure 2D).
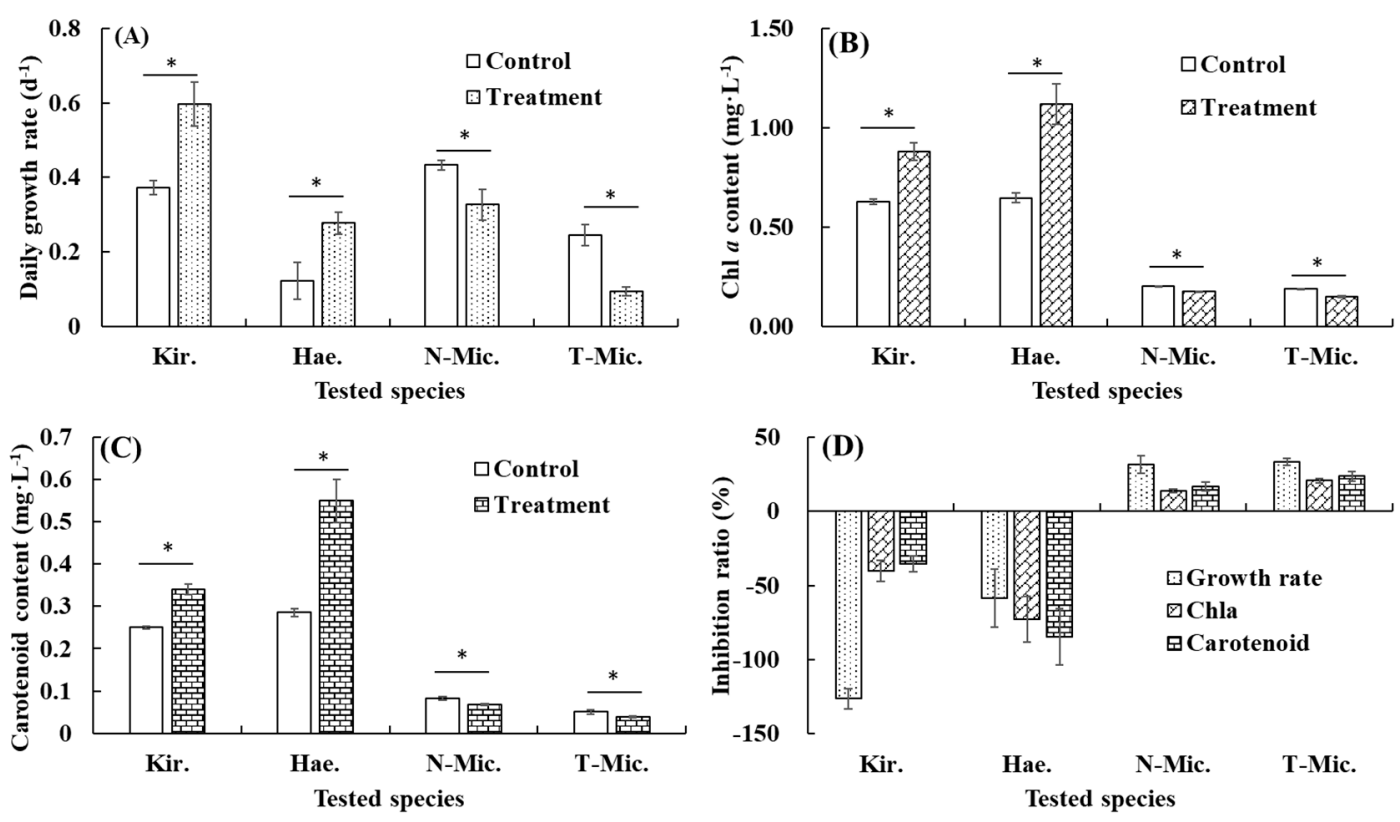

Figure 2. Effects of water extracts from D. indicum flowers at $1.0 \mathrm{~g} \cdot \mathrm{DW} \cdot \mathrm{L}^{-1}$ on daily growth rate (A), chlorophyll $a$ content (B), and carotenoid content (C) of Kirchneriella sp. (Kir.), H. pluvialis (Hae.), and non-toxigenic (N-Mic.) and toxigenic M. aeruginosa (T-Mic.), and the inhibition ratios according to the three parameters (D) during 3-day bioassays. * indicates significant differences between the control and the treatment at $p<0.05$ level.

\subsection{Effects of Water Extraction Temperature on Cyanoabcterial Inhibition by Aqueous Extracts of D. indicum Flowers}

There was no significant difference in the responses of $M$. aeruginosa to water-soluble substances extracted from $D$. indicum flowers in normal temperature water $\left(25^{\circ} \mathrm{C}\right)$ or boiling water $\left(100^{\circ} \mathrm{C}\right)$ during a 9-day bioassay ( $p>0.05$, Figure 3). The cell density and chl $a$ concentration of $M$. aeruginos $a$ in the control increased 27-fold and 14-fold from day 0 to day 9, respectively. However, the cell density and chl $a$ concentration of $M$. aeruginosa treated with both kinds of plant aqueous extracts increased only twofold (Figure $3 \mathrm{~A}, \mathrm{~B})$. The corresponding inhibition ratios increased over time for both treatments. The inhibition ratios of the plant extracts prepared with water at $25{ }^{\circ} \mathrm{C}$ and $100{ }^{\circ} \mathrm{C}$ reached up to $93.1 \%$ and $93.6 \%$ compared to the cell density in the control, and $86.1 \%$ and $89.1 \%$ relative to the chl $a$ concentration of M. aeruginosa in the control on day 9 (Figure 3C,D). 

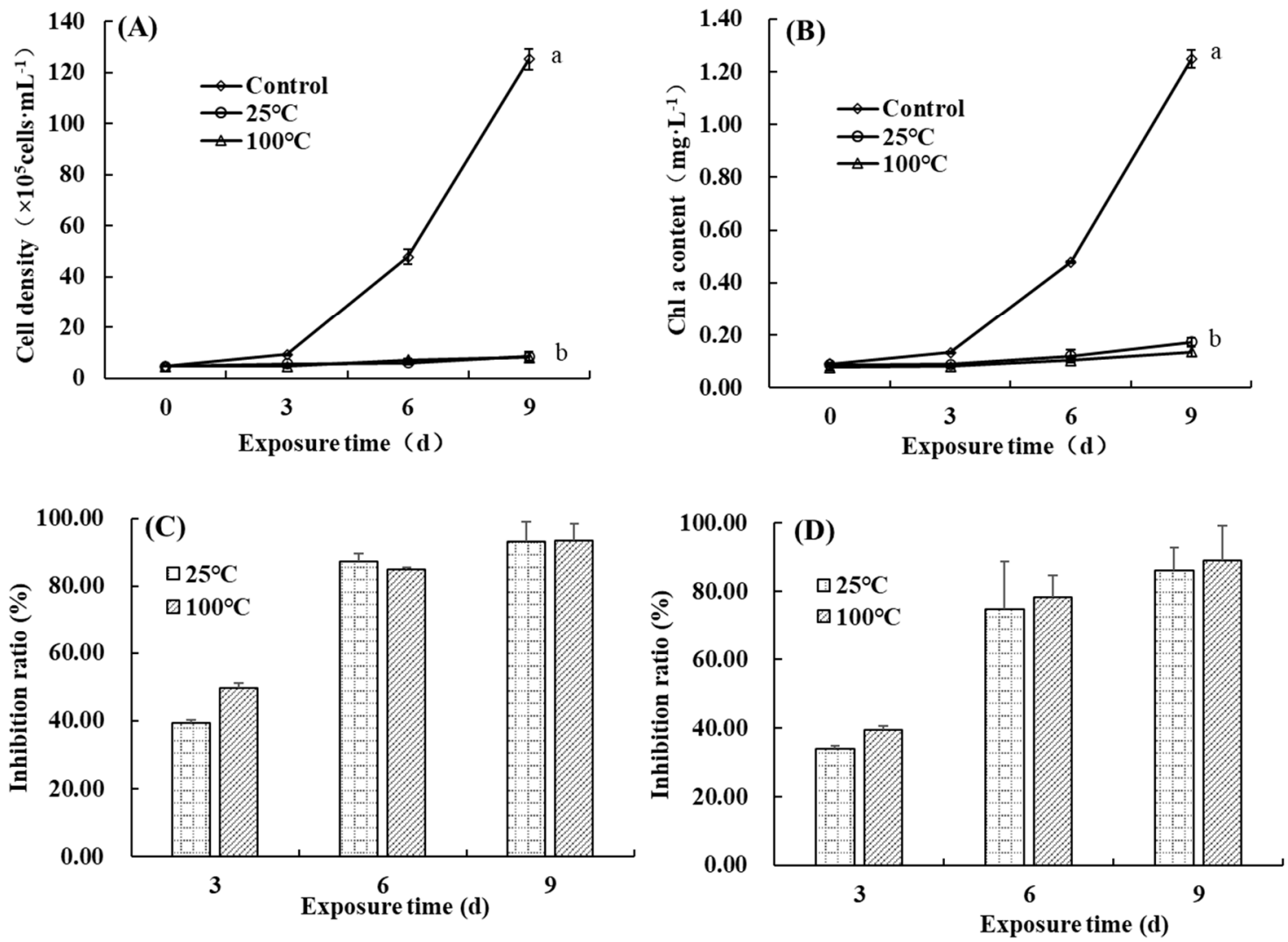

Figure 3. Cell density (A) and chl $a$ content (B) of $M$. aeruginosa in response to water-soluble substances extracted from $D$. indicum flowers at $2.0 \mathrm{~g} \cdot \mathrm{DW} \cdot \mathrm{L}^{-1}$ with normal temperature water $\left(25^{\circ} \mathrm{C}\right)$ and boiling water $\left(100{ }^{\circ} \mathrm{C}\right)$, and the corresponding inhibition ratio in terms of cell density $(\mathbf{C})$ and chl $a$ content (D) in a 9-day bioassay. Different letters indicate significant differences among different groups at $p<0.05$ level.

The fast chlorophyll fluorescence induction curves of $M$. aeruginos $a$ treated with aqueous extracts of $D$. indicum flowers using water at $25^{\circ} \mathrm{C}$ and $100{ }^{\circ} \mathrm{C}$ showed no significant difference $(p>0.05)$, but were significantly lower than that in the control $(p<0.05$, Figure 4$)$. The fluorescence intensity at $2 \mathrm{~ms}\left(\mathrm{~F}_{\mathrm{j}}\right)$ and $30 \mathrm{~ms}\left(\mathrm{~F}_{\mathrm{i}}\right)$ and the maximum fluorescence intensity $\left(\mathrm{F}_{\mathrm{p}}\right)$ of M. aeruginosa cells in the control increased 5.1, 5.3, and 5.8-fold from day 3 to day 9. However, the extent of the increase of the corresponding values was lower than 2.0-fold in both treatments. The gap between the control and the treatments increased over time. Compared to the control, the $\mathrm{F}_{\mathrm{p}}$ values decreased by $79.65 \%$ and $84.22 \%$ in the treatments with normal temperature water $\left(25^{\circ} \mathrm{C}\right)$ and boiling water $\left(100{ }^{\circ} \mathrm{C}\right)$ on day 9 , respectively.

The parameters extracted from OJIP curves using JIP test analysis, including Fv/Fm, $\psi_{\mathrm{o}}, \varphi$ Eo, and PIABS of $M$. aeruginosa cells in both treatments, showed no obvious differences $(p>0.05)$, but were significantly lower than those in the control $(p<0.05)$ after 9 days. The ETo/RC of M. aeruginosa cells in both treatments was also significantly lower than that in the control $(p<0.05)$. The values of $\mathrm{ABS} / \mathrm{RC}$ and DIo/RC of M. aeruginosa in both treatments were higher than those in the control, and the differences between the control and the treatments increased over time. However, there was no significant difference in TRo/RC between the control and the treatments (Table 2). 

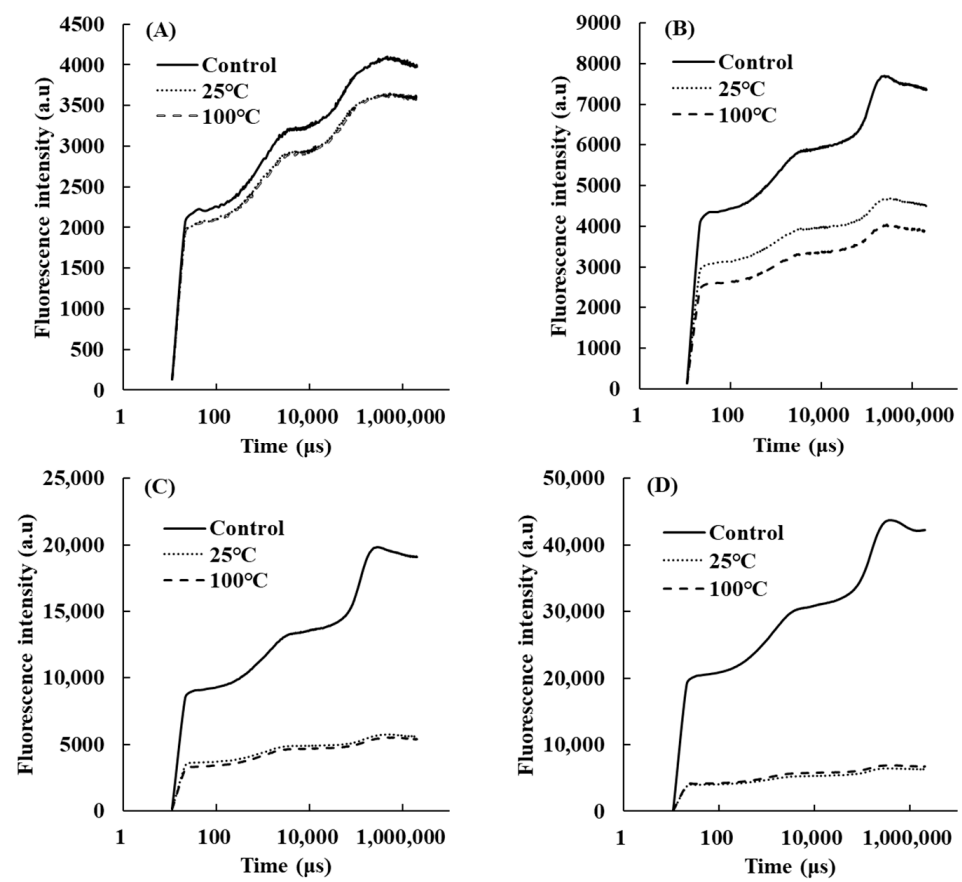

Figure 4. The fast chlorophyll fluorescence induction curves of $M$. aeruginosa in response to water-soluble substances extracted from $D$. indicum flowers at $2.0 \mathrm{~g} \cdot \mathrm{DW} \cdot \mathrm{L}^{-1}$ with normal temperature water $\left(25^{\circ} \mathrm{C}\right)$ and boiling water $\left(100^{\circ} \mathrm{C}\right)$ during a 9-day bioassay. (A) day 0 ; (B) day 3; (C) day 6; (D) day 9.

Table 2. The JIP test parameters of $M$. aeruginosa in response to water-soluble substances extracted from $D$. indicum flowers at $2.0 \mathrm{~g} \cdot \mathrm{DW} \cdot \mathrm{L}^{-1}$ with normal temperature water $\left(25^{\circ} \mathrm{C}\right)$ and boiling water $\left(100{ }^{\circ} \mathrm{C}\right)$ in a 9-day bioassay. Different letters indicate significant differences among the control and the treatments on the same day at $p<0.05$ level.

\begin{tabular}{|c|c|c|c|c|}
\hline \multirow{2}{*}{ Parameters } & \multirow{2}{*}{ Time } & \multicolumn{3}{|c|}{ Treatments } \\
\hline & & Control & $25^{\circ} \mathrm{C}$ & $100^{\circ} \mathrm{C}$ \\
\hline \multirow{3}{*}{$\mathrm{Fv} / \mathrm{Fm}$} & day 3 & $0.44 \pm 0.01^{\mathrm{a}}$ & $0.36 \pm 0.01^{b}$ & $0.37 \pm 0.01^{b}$ \\
\hline & day 6 & $0.55 \pm 0.01^{\mathrm{a}}$ & $0.36 \pm 0.08^{b}$ & $0.41 \pm 0.04^{b}$ \\
\hline & day 9 & $0.54 \pm 0.01^{\mathrm{a}}$ & $0.41 \pm 0.03^{b}$ & $0.41 \pm 0.04^{b}$ \\
\hline \multirow{3}{*}{$\psi_{\mathrm{o}}$} & day 3 & $0.61 \pm 0.01^{a}$ & $0.55 \pm 0.03^{b}$ & $0.55 \pm 0.02^{b}$ \\
\hline & day 6 & $0.67 \pm 0.01^{\mathrm{a}}$ & $0.49 \pm 0.03^{b}$ & $0.47 \pm 0.02^{b}$ \\
\hline & day 9 & $0.66 \pm 0.02^{\mathrm{a}}$ & $0.58 \pm 0.01^{\mathrm{ab}}$ & $0.53 \pm 0.07^{b}$ \\
\hline \multirow{3}{*}{$\varphi$ Ео } & day 3 & $0.27 \pm 0.01^{a}$ & $0.19 \pm 0.01^{b}$ & $0.21 \pm 0.01^{b}$ \\
\hline & day 6 & $0.37 \pm 0.01^{\mathrm{a}}$ & $0.18 \pm 0.03^{b}$ & $0.19 \pm 0.02^{b}$ \\
\hline & day 9 & $0.35 \pm 0.02^{\mathrm{a}}$ & $0.24 \pm 0.02^{b}$ & $0.21 \pm 0.02^{b}$ \\
\hline \multirow{3}{*}{$\mathrm{ABS} / \mathrm{RC}$} & day 3 & $2.30 \pm 0.17^{\mathrm{a}}$ & $2.86 \pm 0.32^{\mathrm{a}}$ & $2.65 \pm 0.15^{a}$ \\
\hline & day 6 & $1.72 \pm 0.18^{a}$ & $2.72 \pm 0.52^{b}$ & $2.47 \pm 0.25^{a b}$ \\
\hline & day 9 & $1.69 \pm 0.06^{\mathrm{a}}$ & $2.26 \pm 0.30^{b}$ & $2.10 \pm 0.19^{a b}$ \\
\hline \multirow{3}{*}{ TRo/RC } & day 3 & $1.02 \pm 0.09^{\mathrm{a}}$ & $1.02 \pm 0.10^{\mathrm{a}}$ & $0.99 \pm 0.05^{a}$ \\
\hline & day 6 & $0.94 \pm 0.09^{\mathrm{a}}$ & $0.95 \pm 0.07^{\mathrm{a}}$ & $1.00 \pm 0.03^{a}$ \\
\hline & day 9 & $0.91 \pm 0.02^{\mathrm{a}}$ & $0.92 \pm 0.07^{\mathrm{a}}$ & $0.85 \pm 0.11^{\mathrm{a}}$ \\
\hline \multirow{3}{*}{ ETo/RC } & day 3 & $0.62 \pm 0.05^{\mathrm{a}}$ & $0.55 \pm 0.06^{\mathrm{a}}$ & $0.55 \pm 0.04^{a}$ \\
\hline & day 6 & $0.63 \pm 0.06^{\mathrm{a}}$ & $0.47 \pm 0.02^{b}$ & $0.47 \pm 0.01^{b}$ \\
\hline & day 9 & $0.59 \pm 0.01^{\mathrm{a}}$ & $0.53 \pm 0.03^{b}$ & $0.45 \pm 0.00^{c}$ \\
\hline \multirow{3}{*}{ DIo/RC } & day 3 & $1.28 \pm 0.08^{a}$ & $1.85 \pm 0.22^{b}$ & $1.66 \pm 0.12^{\mathrm{ab}}$ \\
\hline & day 6 & $0.78 \pm 0.09^{a}$ & $1.77 \pm 0.56^{b}$ & $1.47 \pm 0.24^{b}$ \\
\hline & day 9 & $0.78 \pm 0.04^{\mathrm{a}}$ & $1.34 \pm 0.23^{b}$ & $1.25 \pm 0.14^{b}$ \\
\hline \multirow{3}{*}{ PIABS } & day 3 & $0.54 \pm 0.05^{\mathrm{a}}$ & $0.23 \pm 0.04^{b}$ & $0.28 \pm 0.03^{b}$ \\
\hline & day 6 & $1.43 \pm 0.22^{\mathrm{a}}$ & $0.21 \pm 0.09^{b}$ & $0.25 \pm 0.06^{b}$ \\
\hline & day 9 & $1.32 \pm 0.20^{\mathrm{a}}$ & $0.44 \pm 0.13^{b}$ & $0.38 \pm 0.10^{b}$ \\
\hline
\end{tabular}




\subsection{Effects of Eluting Solvents on Cyanoabcterial Inhibition by SPE-Enriched Aqueous Extracts of D. indicum Flowers}

SPE-enriched aqueous extracts of $D$. indicum flowers were eluted with five solvents with increasing polarities, i.e., hexane, dichloromethane, ethyl acetate, acetone, and methanol, in sequence. The obtained five eluting fractions showed polarity-dependent inhibition effects on M. aeruginosa (Figure 5). The cell density of $M$. aeruginosa in the control increased 33-fold over 9 days, 43-fold when treated with the hexane fraction, eightfold with the dichloromethane fraction, fivefold with the ethyl acetate fraction, threefold with the acetone fraction, and twofold with the methanol fraction (Figure 5A). The chl $a$ concentration of M. aeruginosa in the control increased 10-fold for 9 days, 12-fold for the hexane fraction, eightfold for the dichloromethane fraction, sevenfold for the ethyl acetate fraction, threefold for the acetone fraction, and twofold for the methanol fraction (Figure 5B). The hexane fraction showed significant promotion effects on $M$. aeruginosa, and the maximum promotion ratio was $28.9 \%$ and $38.6 \%$ in terms of cell density and chl $a$ content, respectively, on day 9. However, the inhibition ratio of the other four eluting fractions was above $50 \%$ from day 3 and increased over time. The inhibition ratio of the methanol fraction on the cell density and chl $a$ content of $M$. aeruginos $a$ was the highest, $94.9 \%$ and $85.6 \%$, on day 9 (Figure 5C,D).
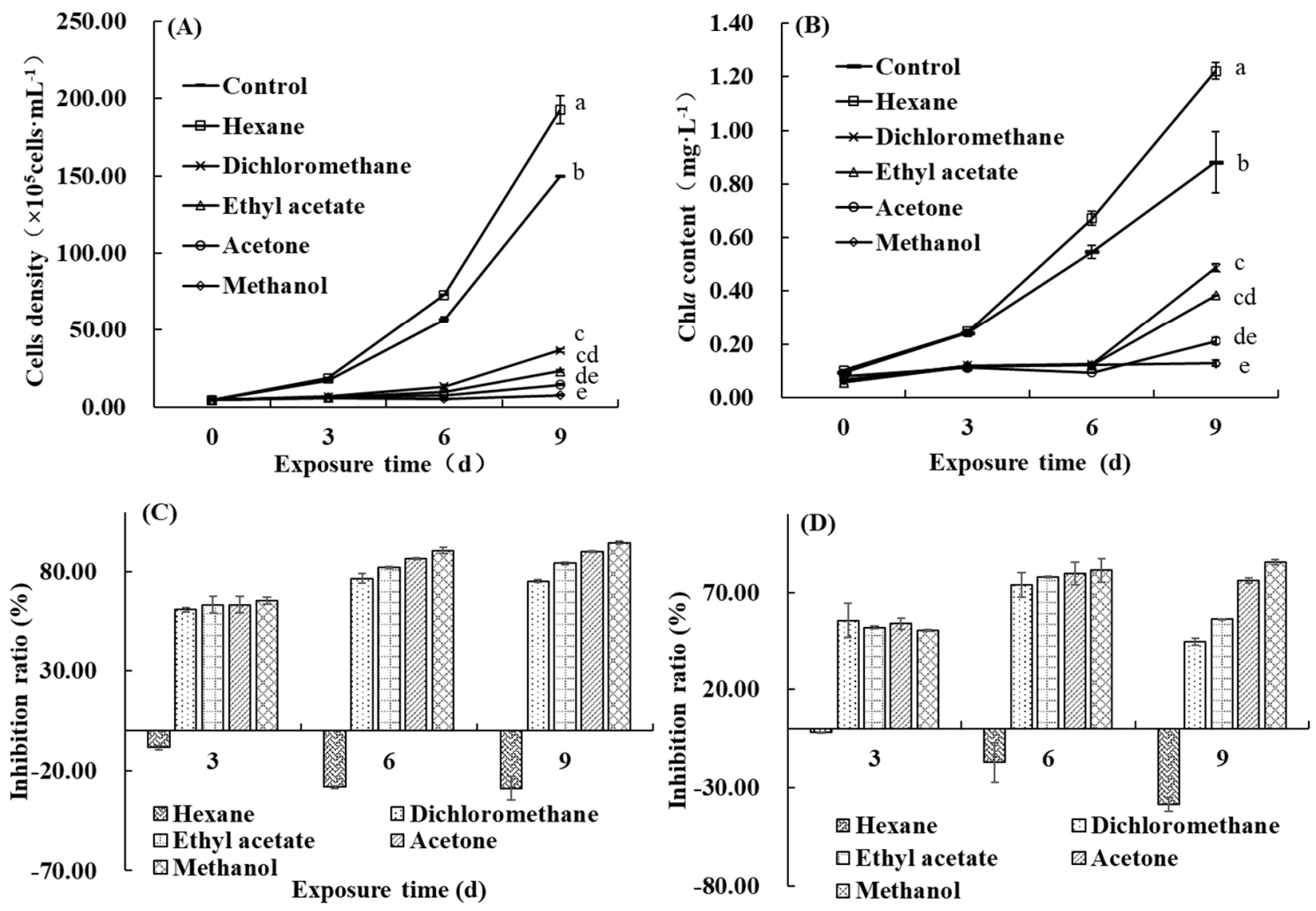

Exposure time (d)

Figure 5. Cell density (A) and chl $a$ content (B) of M. aeruginosa treated with the eluting fractions of SPE-enriched aqueous extracts from D. indicum flowers at $2.0 \mathrm{~g} \cdot \mathrm{DW} \cdot \mathrm{L}^{-1}$ and the corresponding inhibition ratio based on cell density (C) and chl $a$ content (D) in a 9-day bioassay. Different letters indicate significant differences among different groups at $p<0.05$ level.

The polarity-dependent inhibition effects of aqueous extracts from $D$. indicum flowers on the fast chlorophyll fluorescence induction curves of $M$. aeruginosa were also observed (Figure 6). The $F_{j}, F_{i}$, and $F_{p}$ values of the typical OJIP curves of M. aeruginosa in the control increased 5.2, 5.2, and 4.8-fold from day 3 to day 9. The addition of the hexane fraction promoted the chlorophyll fluorescence intensity of $M$. aeruginosa compared to the control. However, the other four fractions showed strong 
inhibition effects, and the inhibition degree enhanced with the polarity of the solvents. The differences increased with time. The $\mathrm{F}_{\mathrm{p}}$ value increased by $5.04 \%$ for the hexane fraction, and decreased by $60.51 \%$ for the dichloromethane fraction, $71.97 \%$ for the ethyl acetate fraction, $85.62 \%$ for the acetone fraction, and $92.32 \%$ for the methanol fraction by day 9 .
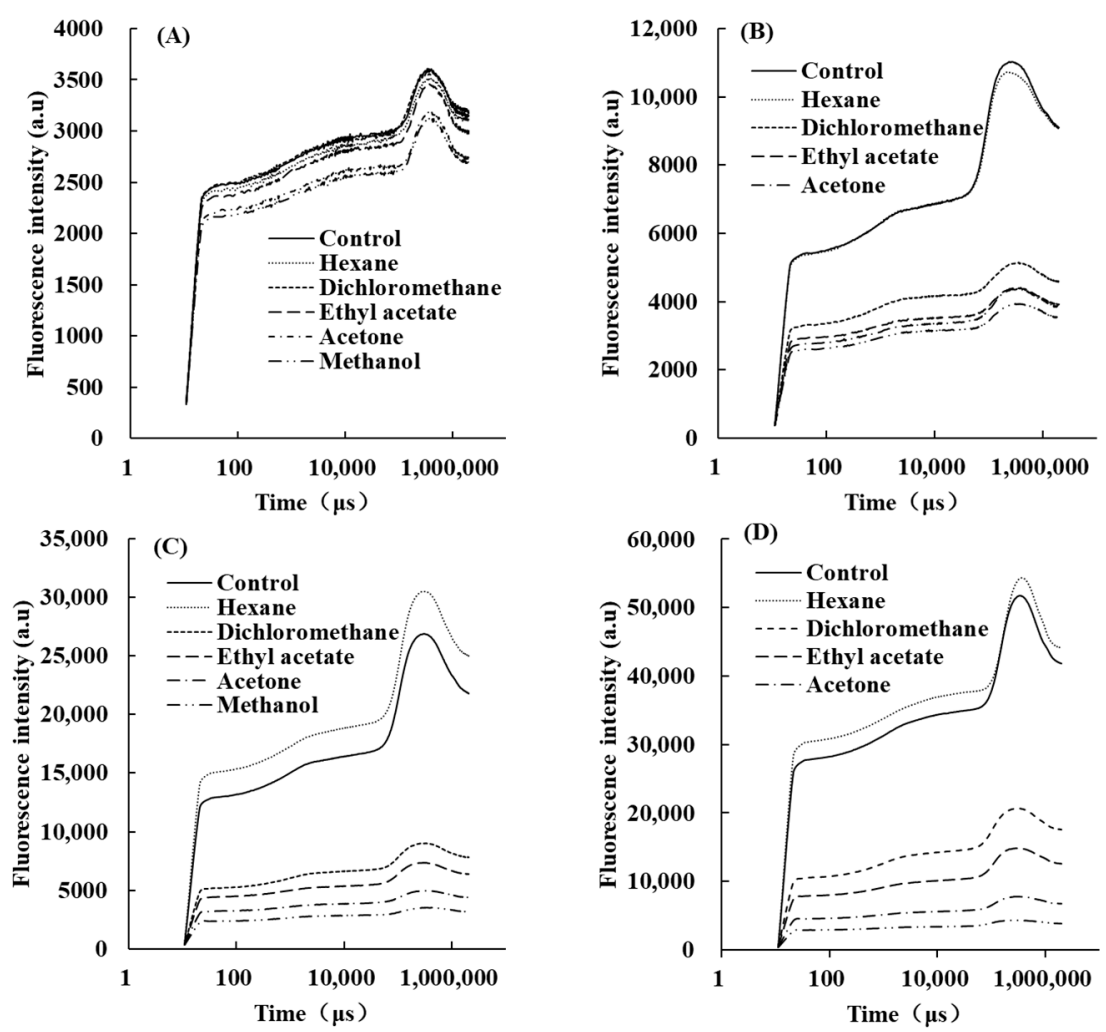

Figure 6. The fast chlorophyll fluorescence curves of M. aeruginosa treated with the eluting fractions of SPE-enriched aqueous extracts from D. indicum flowers at $2.0 \mathrm{~g} \cdot \mathrm{DW} \cdot \mathrm{L}^{-1}$. (A) Day 0; (B) day 3; (C) day 6; (D) day 9 .

The parameters extracted from the OJIP curves of M. aeruginosa cells were affected by eluting fractions of $D$. indicum flowers (Table 3). There were no significant differences in $\mathrm{Fv} / \mathrm{Fm}$ values between the control and the hexane fraction $(p>0.05)$. The Fv/Fm values of $M$. aeruginosa cells treated with the other four eluting fractions showed obvious polarity-dependent decreases on day 6 and day 9 and were significantly lower than that in the control $(p<0.05)$. The Fv/Fm value of M. aeruginosa cells treated with the methanol fraction was the lowest, as it decreased by $28.50 \%$ on day $3,29.11 \%$ on day 6 , and $32.01 \%$ on day 9 . The $\psi_{\mathrm{o}}$ value of $M$. aeruginosa for the control and hexane fraction was significantly higher than that for the other four fractions $(p<0.05)$. It increased slightly for all the treatments from day 3 to day 9 . The $\varphi$ Eo value of $M$. aeruginosa cells in the control and hexane fraction showed no significant differences $(p>0.05)$ but were significantly higher than those in the other four fractions $(p<0.05)$. It increased slightly for the four eluting fractions with higher polarity from day 3 to day 9 , and the polarity-dependent inhibition was obvious on day 6 and day 9 . The ABS/RC and $\mathrm{DIo} / \mathrm{RC}$ values did not show strict polarity-dependent tendencies, but they were the highest in the methanol fraction. The values of TRo/RC and ETo/RC of $M$. aeruginosa for the dichloromethane fraction and ethyl acetate fraction were the lowest, but they were not significantly different from those for the acetone and methanol fractions in most cases $(p>0.05)$. The PIABS values of $M$. aeruginosa showed decreasing trends, along with an increase in solvent polarity, with the lowest for the methanol fraction on day 6 and day 9. The inhibition ratio of PIABS values in M. aeruginosa cells by the methanol fraction was $76.84 \%$ on day $3,81.24 \%$ on day 6 , and $72.02 \%$ on day 9 compared to that in the control. 
Table 3. The JIP test parameters of M. aeruginosa treated with the eluting fractions of SPE-enriched aqueous extracts from $D$. indicum flowers at $2.0 \mathrm{~g} \cdot \mathrm{DW} \cdot \mathrm{L}^{-1}$ in a 9-day bioassay. Different letters indicate significant differences among the control and the treatments on the same day at $p<0.05$ level.

\begin{tabular}{|c|c|c|c|c|c|c|c|}
\hline \multirow{2}{*}{ Parameters } & \multirow{2}{*}{ Time } & \multicolumn{6}{|c|}{ Treatments } \\
\hline & & Control & Hexane & Dichloromethane & Ethyl Acetate & Acetone & Methanol \\
\hline \multirow{3}{*}{$\mathrm{Fv} / \mathrm{Fm}$} & day 3 & $0.53 \pm 0.01^{\mathrm{a}}$ & $0.52 \pm 0.01 \mathrm{a}$ & $0.38 \pm 0.02^{b}$ & $0.37 \pm 0.01^{b}$ & $0.40 \pm 0.01^{b}$ & $0.38 \pm 0.01^{b}$ \\
\hline & day 6 & $0.53 \pm 0.01^{\mathrm{a}}$ & $0.51 \pm 0.01^{\mathrm{a}}$ & $0.44 \pm 0.00^{\mathrm{b}}$ & $0.42 \pm 0.01^{b}$ & $0.38 \pm 0.01^{c}$ & $0.37 \pm 0.01^{\mathrm{c}}$ \\
\hline & day 9 & $0.53 \pm 0.02^{\mathrm{a}}$ & $0.51 \pm 0.01^{\mathrm{a}}$ & $0.50 \pm 0.00^{\mathrm{ab}}$ & $0.48 \pm 0.01^{\mathrm{b}}$ & $0.44 \pm 0.01^{\mathrm{c}}$ & $0.36 \pm 0.01^{d}$ \\
\hline \multirow{3}{*}{$\psi_{\mathrm{o}}$} & day 3 & $0.79 \pm 0.01^{\mathrm{a}}$ & $0.77 \pm 0.03^{\mathrm{a}}$ & $0.61 \pm 0.01^{\mathrm{c}}$ & $0.66 \pm 0.01^{b}$ & $0.70 \pm 0.01^{b}$ & $0.68 \pm 0.02^{b}$ \\
\hline & day 6 & $0.80 \pm 0.01^{\mathrm{a}}$ & $0.81 \pm 0.00^{\mathrm{a}}$ & $0.69 \pm 0.01 \mathrm{~cd}$ & $0.74 \pm 0.01^{b}$ & $0.71 \pm 0.01 \mathrm{bc}$ & $0.66 \pm 0.03^{d}$ \\
\hline & day 9 & $0.79 \pm 0.03^{\mathrm{a}}$ & $0.81 \pm 0.01^{\mathrm{a}}$ & $0.71 \pm 0.01^{\mathrm{b}}$ & $0.75 \pm 0.02^{b}$ & $0.74 \pm 0.00^{b}$ & $0.74 \pm 0.01^{b}$ \\
\hline \multirow{3}{*}{$\varphi$ Еo } & day 3 & $0.42 \pm 0.01^{\mathrm{a}}$ & $0.40 \pm 0.02^{\mathrm{a}}$ & $0.23 \pm 0.02^{b}$ & $0.24 \pm 0.01^{b}$ & $0.28 \pm 0.01^{b}$ & $0.25 \pm 0.00^{b}$ \\
\hline & day 6 & $0.42 \pm 0.01^{\mathrm{a}}$ & $0.41 \pm 0.01^{\mathrm{a}}$ & $0.31 \pm 0.01^{b}$ & $0.31 \pm 0.01^{b}$ & $0.27 \pm 0.01^{c}$ & $0.25 \pm 0.01^{d}$ \\
\hline & day 9 & $0.37 \pm 0.03^{\mathrm{a}}$ & $0.36 \pm 0.01^{\mathrm{a}}$ & $0.36 \pm 0.01^{\mathrm{a}}$ & $0.36 \pm 0.01^{\mathrm{a}}$ & $0.32 \pm 0.01^{b}$ & $0.27 \pm 0.00^{c}$ \\
\hline \multirow{3}{*}{ ABS/RC } & day 3 & $2.43 \pm 0.23^{\mathrm{a}}$ & $2.51 \pm 0.25^{\mathrm{a}}$ & $3.03 \pm 0.44^{\mathrm{a}}$ & $3.69 \pm 0.74^{\mathrm{a}}$ & $2.88 \pm 0.20^{\mathrm{a}}$ & $3.16 \pm 0.21^{\mathrm{a}}$ \\
\hline & day 6 & $2.36 \pm 0.07^{b}$ & $2.51 \pm 0.09^{b}$ & $2.40 \pm 0.06^{b}$ & $2.96 \pm 0.04^{\mathrm{ab}}$ & $2.88 \pm 0.34^{\mathrm{ab}}$ & $3.44 \pm 0.54^{\mathrm{a}}$ \\
\hline & day 9 & $2.43 \pm 0.06^{\mathrm{b}}$ & $2.93 \pm 0.12^{b}$ & $2.16 \pm 0.12^{c}$ & $2.26 \pm 0.07^{c}$ & $2.71 \pm 0.20^{\mathrm{b}}$ & $3.31 \pm 0.08^{a}$ \\
\hline \multirow{3}{*}{ TRo/RC } & day 3 & $1.28 \pm 0.11^{\mathrm{a}}$ & $1.30 \pm 0.13^{\mathrm{a}}$ & $1.16 \pm 0.11^{\mathrm{a}}$ & $1.37 \pm 0.28^{\mathrm{a}}$ & $1.16 \pm 0.08^{\mathrm{a}}$ & $1.19 \pm 0.10^{\mathrm{a}}$ \\
\hline & day 6 & $1.24 \pm 0.03^{\mathrm{a}}$ & $1.29 \pm 0.04^{\mathrm{a}}$ & $1.06 \pm 0.02^{b}$ & $1.24 \pm 0.05^{\mathrm{a}}$ & $1.10 \pm 0.17^{b}$ & $1.28 \pm 0.22^{\mathrm{a}}$ \\
\hline & day 9 & $1.24 \pm 0.06^{\mathrm{a}}$ & $1.30 \pm 0.02^{\mathrm{a}}$ & $1.08 \pm 0.06^{\mathrm{b}}$ & $1.09 \pm 0.03^{b}$ & $1.19 \pm 0.06^{\mathrm{ab}}$ & $1.19 \pm 0.03^{a b}$ \\
\hline \multirow{3}{*}{$\mathrm{ETo} / \mathrm{RC}$} & day 3 & $1.01 \pm 0.09^{\mathrm{a}}$ & $1.00 \pm 0.13^{\mathrm{a}}$ & $0.71 \pm 0.06^{b}$ & $0.90 \pm 0.18^{\mathrm{a}}$ & $0.81 \pm 0.06^{\mathrm{ab}}$ & $0.80 \pm 0.05^{\mathrm{ab}}$ \\
\hline & day 6 & $0.99 \pm 0.0^{\mathrm{a}}$ & $1.04 \pm 0.03^{\mathrm{a}}$ & $0.73 \pm 0.03^{b}$ & $0.92 \pm 0.04^{\mathrm{ab}}$ & $0.78 \pm 0.11^{b}$ & $0.84 \pm 0.11^{\mathrm{a}}$ \\
\hline & day 9 & $0.98 \pm 0.08^{\mathrm{a}}$ & $1.05 \pm 0.01^{\mathrm{a}}$ & $0.77 \pm 0.04^{b}$ & $0.82 \pm 0.04^{b}$ & $0.88 \pm 0.04^{\mathrm{ab}}$ & $0.88 \pm 0.02^{a b}$ \\
\hline \multirow{3}{*}{$\mathrm{DIo} / \mathrm{RC}$} & day 3 & $1.15 \pm 0.12^{\mathrm{a}}$ & $1.21 \pm 0.12^{\mathrm{ab}}$ & $1.87 \pm 0.33^{b}$ & $2.33 \pm 0.46^{b}$ & $1.71 \pm 0.12^{b}$ & $1.97 \pm 0.11^{b}$ \\
\hline & day 6 & $1.12 \pm 0.06^{\mathrm{a}}$ & $1.22 \pm 0.07^{\mathrm{a}}$ & $1.34 \pm 0.04 \mathrm{ab}$ & $1.72 \pm 0.03^{b}$ & $1.79 \pm 0.17 \mathrm{bc}$ & $2.15 \pm 0.32^{c}$ \\
\hline & day 9 & $1.42 \pm 0.05^{\mathrm{b}}$ & $1.63 \pm 0.09^{b}$ & $1.08 \pm 0.07^{c}$ & $1.16 \pm 0.04^{c}$ & $1.52 \pm 0.14^{\mathrm{b}}$ & $2.12 \pm 0.06^{\mathrm{a}}$ \\
\hline \multirow{3}{*}{ PIABS } & day 3 & $1.73 \pm 0.23^{\mathrm{a}}$ & $1.43 \pm 0.24^{\mathrm{a}}$ & $0.33 \pm 0.09^{b}$ & $0.32 \pm 0.08^{b}$ & $0.55 \pm 0.06^{b}$ & $0.40 \pm 0.04^{b}$ \\
\hline & day 6 & $1.86 \pm 0.14^{\mathrm{a}}$ & $1.75 \pm 0.12^{\mathrm{a}}$ & $0.74 \pm 0.04^{b}$ & $0.70 \pm 0.05^{b}$ & $0.54 \pm 0.06^{b}$ & $0.35 \pm 0.10^{c}$ \\
\hline & day 9 & $1.73 \pm 0.29^{a}$ & $1.13 \pm 0.13^{\mathrm{a}}$ & $1.13 \pm 0.09^{a}$ & $1.08 \pm 0.00^{\mathrm{a}}$ & $0.82 \pm 0.10^{\mathrm{ab}}$ & $0.48 \pm 0.01^{b}$ \\
\hline
\end{tabular}

\section{Discussion}

\subsection{Selective Growth Inhibition of Cyanobacteria and the Promotion of Green Algae by Aqueous Extracts of D. indicum Flowers}

A high phytoplankton abundance with a healthy community structure is necessary to improve fishery productivity and the water environment of aquaculture ponds [32,33]. Mechanical removal, water change, engineering measures, and investment in chemical algicides are normally used to control harmful cyanobacteria blooms occurring in the middle and late stages of pond culture [15,34,35]. Nutrient enrichment and the addition of beneficial algae are traditionally used to improve the phytoplankton abundance and structure during the early stage of aquaculture [36,37]. The present study provides a new way to promote green algae and inhibit $M$. aeruginosa simultaneously by aqueous extracts of $D$. indicum flowers. The anti-inflammatory and antimicrobial activities of $D$. indicum extract have been reported [38,39], and our findings reveal its potential to selectively control harmful cyanobacteria and regulate phytoplankton composition to improve fishery productivity in aquaculture ponds.

The concentration-dependent inhibition effects of the aqueous extracts of $D$. indicum flowers on $M$. aeruginosa were found in our bioassays. It is consistent with previous studies showing the concentration-dependent allelopathic effects of aquatic plants on cyanobacteria [40]. Their promotion effects on the green algae C. vulgaris were obvious with a slightly enhanced trend when the flower concentration increased from 0.5 to $2.0 \mathrm{~g} \cdot \mathrm{DW} \cdot \mathrm{L}^{-1}$, whereas their concentration-dependent inhibition effects on C. vulgaris were obvious when the flower concentration ranged from 4.0 to $8.0 \mathrm{~g} \cdot \mathrm{DW} \cdot \mathrm{L}{ }^{-1}$. These results indicated that the added dose played a critical role in the selective inhibition of harmful cyanobacteria by the aqueous extracts of $D$. indicum flowers. The concentration range of the plant extracts to exhibit the selective inhibition of harmful cyanobacteria and the promotion of beneficial 
eukaryotic algae needs to be ascertained at larger and longer timescales to ensure their successful application in the restoration of healthy phytoplankton communities in aquaculture ponds.

\subsection{Chemical Characteristics of the Selective Inhibition Substances of D. indicum Flowers}

The significant inhibition of M. aeruginosa and the promotion of green algae by aqueous extracts of $D$. indicum flowers were observed under identical culture conditions, excluding nutrients and light limitation or the impacts of any coexisting organisms. It indicated that there must be some water-soluble active substances derived from $D$. indicum flowers contributing to the selective inhibition effects on M. aeruginosa. There was no significant difference in inhibition effects on $M$. aeruginosa by aqueous extracts prepared with water at $25^{\circ} \mathrm{C}$ and $100{ }^{\circ} \mathrm{C}$. It indicated that the selective inhibition substances of $D$. indicum flowers were thermally stable. The methanol fraction eluted from SPE-enriched aqueous extracts of $D$. indicum flowers showed the strongest inhibition on $M$. aeruginosa compared to the other four fractions. It indicated that the most polar substances of $D$. indicum flowers were responsible for the selective inhibition of $M$. aeruginosa. These results together provided clues to reveal the basic chemical characteristics of selective inhibition substances of $D$. indicum flowers for M. aeruginosa. It was very helpful for us to identify the specific substances and their application in the ecological control of harmful cyanobacteria and the regulation of phytoplankton composition. Duddleoside, luteolin, chlorogenic acid, caffeic acid, and 3,5-dicaffeoylquinic acid were typical active substances of $D$. indicum flowers [41]. Flavonoids, including linatin, luteolin, quercetin, and apigenin, were detected in $D$. indicum flowers from various locations in China [42]. Luteolin showed the strongest inhibition effects on the growth and photosynthesis activity of $M$. aeruginosa from among the selected three flavonoids [43]. Whether these co-existing substances contribute to the selective inhibition of cyanobacteria needs further research.

\subsection{Photosynthetic Activity of M. aeruginosa Treated with Water-Soluble Substances of D. indicum Flowers}

The chlorophyll fluorescence transients and subsequent JIP test have been widely used to reflect the status and behavior of PSII in phototrophs, including plants and phytoplankton [31,44]. The obvious decrease in the fluorescence transients of $M$. aeruginosa treated with aqueous extracts of $D$. indicum flowers indicated that the successive reduction in the electron acceptor pools of PSII, including $Q_{A}, Q_{B}$, and PQ pool, was seriously affected by water soluble substances extracted from $D$. indicum flowers [31]. The parameter $\mathrm{Fv} / \mathrm{Fm}$, the maximum quantum yield of primary photochemistry, has been widely used to reflect the potential photosynthetic capacity of PSII in phototrophs $[31,43]$. The inhibition ratios of the $\mathrm{Fv} / \mathrm{Fm}$ values of $M$. aeruginos $a$ by aqueous extracts of $D$. indicum flowers and the methanol eluting fractions were higher than $20 \%$ in most cases. The parameter PIABS reflects the performance index on an absorption basis, which is the combination of three independent parameters, including RC/ABS, $\mathrm{Fv} / \mathrm{Fm}$, and $\psi_{\mathrm{o}}$ [31]. Its values decreased by more than $50 \%$ in the treatments with aqueous extracts of $D$. indicum flowers and the methanol eluting fractions. The extent of the change in PIABS was more consistent with the extent of the change in cell density and chl $a$ of $M$. aeruginosa than $\mathrm{Fv} / \mathrm{Fm}$, which was also found in previous literature [44]. The significant decrease in $\psi \mathrm{o}, \varphi \mathrm{Eo}$, and ETo/RC indicated that the performance of electron transfer from $\mathrm{Q}_{\mathrm{A}}{ }^{-}$to $\mathrm{Q}_{\mathrm{B}}$ was seriously inhibited by polar active substances of $D$. indicum flowers, and the acceptor side of the electron transport of PSII was a target site. The parameter ABS/RC reflects absorption flux per reaction center [45]. The increase in ABS/RC for $M$. aeruginosa treated with aqueous extracts of $D$. indicum flowers and the methanol fraction indicated the changes in the RC number. Since the trapped energy flux per reaction center (TRo/RC) did not change significantly, the decrease in the electron transport flux per reaction center $(\mathrm{ETo} / \mathrm{RC})$ corresponded to the increase in the dissipated energy flux per reaction center (DIo/RC) [31].

\subsection{The Application of Water-Soluble Substances of D. indicum Flowers in Aquaculture Ponds}

The present study provided the possibility to use water-soluble substances of $D$. indicum flowers to selectively control harmful $M$. aeruginosa proliferation and regulate phytoplankton community structure in aquaculture ponds. However, verifying this possibility fully and revealing the 
underlying mechanisms are necessary before its final application. The cyanobacteria proportion in total phytoplankton density treated with aqueous extracts of D. indicum flowers was obviously reduced in our outdoor mesocosms, but the dissolved carbon, nitrogen, and phosphorus concentrations were increased compared to the control (unpublished data). It indicated that a more ecological approach to regulate phytoplankton composition using $D$. indicum flowers was to input the specific responsible substances in aqueous extracts of $D$. indicum flowers in aquaculture ponds. Hence, identifying specific active substances was a crucial step to promote its application.

The well-known benefits to human health and antimicrobial activity also provided a possibility of D. indicum flowers to prevent and cure fish disease and promote the quality of aquatic products [28,29], which needs to be verified experimentally using specific substances isolated from $D$. indicum flowers. Medicinal plant derivatives have been widely used as immunostimulants [46]. Once the responsible substances isolated from $D$. indicum flowers were proved to be eco-friendly cyanocides, enough substance sources for wide application are necessary. In addition to extraction from D. indicum flowers, more plant sources need to be screened, and synthetic analogs are also feasible. Some plant-derived active compounds for medical, agronomic, and environmental applications have been successfully synthesized and commercially obtained [12,31].

\section{Conclusions}

The present study demonstrated the strong growth inhibition of toxigenic and non-toxigenic M. aeruginosa and the obvious growth promotion of green algae, including C. vulgaris, Kirchneriella sp., and $H$. pluvialis, by aqueous extracts of $D$. indicum flowers. The responsible substances of $D$. indicum flowers were thermally stable with high polarity. The acceptor side of the electron transport of PSII was a target site of $M$. aeruginosa cells in response to water-soluble substances of $D$. indicum flowers. More experiments are required to identify the responsible active substances and reveal the underlying mechanisms of aqueous extracts of $D$. indicum flowers to selectively inhibit cyanobacteria and regulate the phytoplankton community structure.

Author Contributions: Conceptualization, Y.G.; methodology, F.Z., J.W. and H.Y.; software, F.Z.; validation, J.D. and M.Z.; formal analysis, Y.G. and F.Z.; writing, Y.G., F.Z. and X.L.; supervision and funding acquisition, Y.G. and X.L. All authors have read and agreed to the published version of the manuscript.

Funding: This research was funded by the National Natural Science Foundation of China (grant number 31700405), the Major Science and Technology Program in Henan Province (grant number 202102310272 and 202102310028), and the Breeding Project of Henan Normal University (grant number HNU20180073).

Conflicts of Interest: The authors declare no conflict of interest.

\section{References}

1. Paerl, H.W.; Otten, T.G. Harmful Cyanobacterial Blooms: Causes, Consequences, and Controls. Microb. Ecol. 2013, 65, 995-1010. [CrossRef]

2. Huisman, J.; Codd, G.A.; Paerl, H.W.; Ibelings, B.W.; Verspagen, J.M.H.; Visser, P.M. Cyanobacterial blooms. Nat. Rev. Microbiol. 2018, 16, 471-483. [CrossRef] [PubMed]

3. Xiao, M.; Li, M.; Reynolds, C.S. Colony formation in the cyanobacterium Microcystis. Biol. Rev. 2018, 93, 1399-1420. [CrossRef] [PubMed]

4. Sinden, A.; Sinang, S.C. Cyanobacteria in aquaculture systems: Linking the occurrence, abundance and toxicity with rising temperatures. Int. J. Environ. Sci. Technol. 2016, 13, 2855-2862. [CrossRef]

5. Rimando, A.M.; Schrader, K.K. Off-Flavors in Aquaculture; American Chemical Society: Washington, DC, USA, 2003.

6. Dai, R.; Wang, P.; Jia, P.; Zhang, Y.; Chu, X.; Wang, Y. A review on factors affecting microcystins production by algae in aquatic environments. World J. Microbiol. Biotechnol. 2016, 32, 1-7. [CrossRef]

7. Gobler, C.J.; Burkholder, J.A.M.; Davis, T.W.; Harke, M.J.; Johengen, T.; Stow, C.A.; Van de Waal, D.B. The dual role of nitrogen supply in controlling the growth and toxicity of cyanobacterial blooms. Harmful Algae 2016, 54, 87-97. [CrossRef] 
8. Paerl, H.W.; Xu, H.; McCarthy, M.J.; Zhu, G.; Qin, B.; Li, Y.; Gardner, W.S. Controlling harmful cyanobacterial blooms in a hyper-eutrophic lake (Lake Taihu, China): The need for a dual nutrient (N \& P) management strategy. Water Res. 2011, 45, 1973-1983.

9. Mitrovic, S.M.; Hardwick, L.; Dorani, F. Use of flow management to mitigate cyanobacterial blooms in the Lower Darling River, Australia. J. Plankton Res. 2011, 33, 229-241. [CrossRef]

10. Visser, P.M.; Ibelings, B.W.; Bormans, M.; Huisman, J. Artificial mixing to control cyanobacterial blooms: A review. Aquat. Ecol. 2016, 50, 423-441. [CrossRef]

11. Matthijs, H.C.P.; Visser, P.M.; Reeze, B.; Meeuse, J.; Slot, P.C.; Wijn, G.; Talens, R.; Huisman, J. Selective suppression of harmful cyanobacteria in an entire lake with hydrogen peroxide. Water Res. 2012, 46, 1460-1472. [CrossRef]

12. Matthijs, H.C.P.; Jančula, D.; Visser, P.M.; Maršálek, B. Existing and emerging cyanocidal compounds: New perspectives for cyanobacterial bloom mitigation. Aquat. Ecol. 2016, 50, 443-460. [CrossRef]

13. Van Wichelen, J.; Vanormelingen, P.; Codd, G.A.; Vyverman, W. The common bloom-forming cyanobacterium Microcystis is prone to a wide array of microbial antagonists. Harmful Algae 2016, 55, 97-111. [CrossRef] [PubMed]

14. Xie, P.; Liu, J. Practical success of biomanipulation using filter-feeding Fish to control cyanobacteria blooms: A synthesis of decades of research and application in a subtropical hypereutrophic lake. Sci. World J. 2001, 1, 337-356. [CrossRef] [PubMed]

15. Zhong, F.; Gao, Y.; Yu, T.; Zhang, Y.; Xu, D.; Xiao, E.; He, F.; Zhou, Q.; Wu, Z. The management of undesirable cyanobacteria blooms in channel catfish ponds using a constructed wetland: Contribution to the control of off-flavor occurrences. Water Res. 2011, 45, 6479-6488. [CrossRef]

16. Blanchard, J.L.; Watson, R.A.; Fulton, E.A.; Cottrell, R.S.; Nash, K.L.; Bryndum-Buchholz, A.; Büchner, M.; Carozza, D.A.; Cheung, W.W.L.; Elliott, J.; et al. Linked sustainability challenges and trade-offs among fisheries, aquaculture and agriculture. Nat. Ecol. Evol. 2017, 1, 1240-1249. [CrossRef] [PubMed]

17. Zhu, J.; Liu, B.; Wang, J.; Gao, Y.; Wu, Z. Study on the mechanism of allelopathic influence on cyanobacteria and chlorophytes by submerged macrophyte (Myriophyllum spicatum) and its secretion. Aquat. Toxicol. 2010, 98, 196-203. [CrossRef] [PubMed]

18. Švanys, A.; Paškauskas, R.; Hilt, S. Effects of the allelopathically active macrophyte Myriophyllum spicatum on a natural phytoplankton community: A mesocosm study. Hydrobiologia 2013, 737, 57-66. [CrossRef]

19. Le Rouzic, B.; Thiébaut, G.; Brient, L. Selective growth inhibition of cyanobacteria species (Planktothrix agardhii) by a riparian tree leaf extract. Ecol. Eng. 2016, 97, 74-78. [CrossRef]

20. Tanuja, P.; Venugopal, N.; Sashidhar, R.B. Development and evaluation of thin-layer chromatography-digital image-based analysis for the quantitation of the botanical pesticide azadirachtin in agricultural matrixes and commercial formulations: Comparison with ELISA. J. AOAC Int. 2007, 90, 857-863. [CrossRef]

21. Tu, Y.Y. Artemisia Annua and Artemisinin-Based Drugs; Chemical Industry Press: Beijing, China, 2009.

22. Van Hai, N. The use of medicinal plants as immunostimulants in aquaculture: A review. Aquaculture 2015, 446, 88-96. [CrossRef]

23. Zhou, K.; Guo, W.; Xu, Y. Advances of research on allelopathic potential in Compositae. Acta Ecol. Sin. 2004, 24, 1776-1784.

24. Rasdi, N.H.M.; Samah, O.A.; Sule, A.; Ahmed, Q.U. Antimicrobial studies of Cosmos caudatus Kunth. (Compositae). J. Med. Plants Res. 2010, 4, 669-673.

25. Bukhari, I.A. The central analgesic and anti-inflammatory activities of the methanolic extract of Carthamus oxycantha. J. Physiol. Pharmacol. 2013, 64, 369-375. [PubMed]

26. Gao, Y.N.; Liu, B.Y.; Ge, F.J.; He, Y.; Lu, Z.Y.; Zhou, Q.H.; Zhang, Y.Y.; Wu, Z.B. Joint effects of allelochemical nonanoic acid, n-phenyl-1-naphtylamine and caffeic acid on the growth of Microcystis aeruginosa. Allelopath. J. 2015, 35, 249-258.

27. Xu, F.; He, W.; Zheng, X.; Zhang, W.; Cai, W.; Tang, Q. Inhibitive effects on Microcystis aeruginosa by Artemisia lavandulaefoli and its three organic solvents extracts. Acta Ecol. Sin. 2010, 30, 745-750.

28. Fang, H.; Guo, Q.; Shen, H. Study on antioxidation ability of essential oil from Dendranthema indicum dry flower in five edible oils. J. Plant Resour. Environ. 2010, 19, 54-59.

29. Liu, X.Q.; Zhang, X.F.; Lee, K.S. Antimicrobial activity of the extracts of Forsythia suspensa and Dendranthema indicum. J. Appl. Biol. Chem. 2005, 48, 29-31.

30. Lichtenthaler, H.K.; Buschmann, C. Chlorophylls and carotenoids: Measurement and characterization by UV-VIS spectroscopy. Curr. Protoc. Food Anal. Chem. 2001, 1, F4.3.1-F4.3.8. [CrossRef] 
31. Ni, L.X.; Acharya, K.; Hao, X.Y.; Li, S.Y.; Li, Y.; Li, Y.P. Effects of artemisinin on photosystem II performance of Microcystis aeruginosa by in vivo chlorophyll fluorescence. Bull. Environ. Contam. Toxicol. 2012, 89, 1165-1169. [CrossRef]

32. Fan, L.; Xu, P.; Wu, W.; Qu, J.; Qiu, L.; Chen, J. Regulation of micro-ecological environment in freshwater aquaculture pond: A review. Chin. J. Ecol. 2013, 32, 3094-3100.

33. Daume, S. The roles of bacteria and micro and macro algae in abalone aquaculture: A review. J. Shellfish Res. 2006, 25, 151-157. [CrossRef]

34. Cong, H.; Sun, F.; Wu, J.; Zhou, Y.; Yan, Q.; Ren, A.; Xu, H. Study on method and mechanism of deep well circulation for the growth control of Microcystis in aquaculture pond. Water Sci. Technol. 2017, 75, 2692-2701. [CrossRef] [PubMed]

35. Smith, J.L.; Boyer, G.L.; Zimba, P.V. A review of cyanobacterial odorous and bioactive metabolites: Impacts and management alternatives in aquaculture. Aquaculture 2008, 280, 5-20. [CrossRef]

36. Qin, J.; Culver, D.A.; Yu, N. Effect of organic fertilizer on heterotrophs and autotrophs: Implications for water quality management. Aquac. Res. 1995, 26, 911-920. [CrossRef]

37. Terziyski, D.; Grozev, G.; Kalchev, R.; Stoeva, A. Effect of organic fertilizer on plankton primary productivity in fish ponds. Aquac. Int. 2007, 15, 181-190. [CrossRef]

38. Lee, D.Y.; Choi, G.; Yoon, T.; Cheon, M.S.; Choo, B.K.; Kim, H.K. Anti-inflammatory activity of Chrysanthemum indicum extract in acute and chronic cutaneous inflammation. J. Ethnopharmacol. 2009, 123, 149-154. [CrossRef]

39. Shunying, Z.; Yang, Y.; Huaidong, Y.; Yue, Y.; Guolin, Z. Chemical composition and antimicrobial activity of the essential oils of Chrysanthemum indicum. J. Ethnopharmacol. 2005, 96, 151-158. [CrossRef]

40. Chen, X.; Huang, G.; Fu, H.; An, C.; Yao, Y.; Cheng, G.; Suo, M. Allelopathy inhibitory effects of Hydrodictyon reticulatum on Chlorella pyrenoidosa under co-culture and liquor-cultured conditions. Water 2017, 9, 416. [CrossRef]

41. Zhang, L.; Dai, Q. Determination of active ingredients in flos Chrysanthemi Indici. Guangdong Chem. Ind. 2019, 46, 195-196.

42. He, D.; Zhang, W.; Qin, M. Content analysis of flavonoids in Dendranthema indicum flower from different locations by HPLC. J. Plant Resour. Environ. 2009, 18, 91-93.

43. Huang, H.; Xiao, X.; Ghadouani, A.; Wu, J.; Nie, Z.; Peng, C.; Xu, X.; Shi, J. Effects of natural flavonoids on photosynthetic activity and cell integrity in Microcystis aeruginosa. Toxins 2015, 7, 66-80. [CrossRef] [PubMed]

44. Zhang, L.; Peng, X.; Liu, B.; Zhang, Y.; Zhou, Q.; Wu, Z. Effects of the decomposing liquid of Cladophora oligoclona on Hydrilla verticillata turion germination and seedling growth. Ecotoxicol. Environ. Saf. 2018, 157, 81-88. [CrossRef] [PubMed]

45. Appenroth, K.J.; Stöckel, J.; Srivastava, A.; Strasser, R.J. Multiple effects of chromate on the photosynthetic apparatus of Spirodela polyrhiza as probed by OJIP chlorophyll a fluorescence measurements. Environ. Pollut. 2001, 115, 49-64. [CrossRef]

46. Vaseeharan, B.; Thaya, R. Medicinal plant derivatives as immunostimulants: An alternative to chemotherapeutics and antibiotics in aquaculture. Aquac. Int. 2014, 22, 1079-1091. [CrossRef]

(C) 2020 by the authors. Licensee MDPI, Basel, Switzerland. This article is an open access article distributed under the terms and conditions of the Creative Commons Attribution (CC BY) license (http://creativecommons.org/licenses/by/4.0/). 